\title{
ANALISIS PENGARUH KINERJA LEMBAGA KEUANGAN MIKRO SYARIAH TERHADAP PERKEMBANGAN UNIT USAHA MIKRO, KECIL DAN MENENGAH
}

\author{
$1^{*}$ Agus Suprayogi, ${ }^{2}$ Hafifuddin \\ ${ }^{1}$ STIE Hidayatullah, Depok, Jawa Barat, Indonesia \\ 1*agus.suprayogi@gmail.com, $\underline{2 h . a f i f u d d i n 81 @ g m a i l . c o m ~}$
}

\begin{abstract}
Abstrak
Tujuan penelitian ini adalah untuk melihat pengaruh kinerja Lembaga Keuangan Mikro Syariah yakni Likuiditas dan Solvabilitas terhadap perkembangan UMKM periode tahun 2016 - 2018. Metode analisis data yang di pergunakan adalah analisis regresi linear berganda. Populasi yang di pakai adalah data Kinerja Keuangan Lembaga Keuangan Mikro Syariah yakni Likuiditas dan Solvabilitas dan Data Perkembangan Unit UMKM yang ada di Indonesia pada periode tahun 2016 - 2018. Hasil penelitian ini menunjukkan bahwa Likuiditas dan Solvabilitas berpengaruh terhadap perkembangan UMKM baik secara parsial (sendiri sendiri) dan simultan (bersama - sama)

Kata Kunci: Kinerja, Mikro, UMKM
\end{abstract}

\section{Abstract}

The purpose of this study is to see the effect of the performance of Islamic Microfinance Institutions namely Liquidity and Solvency on the development of MSMEs for the period 20162018. The data analysis method used is multiple linear regression analysis. The population used is the Financial Performance data of Islamic Microfinance Institutions, namely Liquidity and Solvency and Development Data of MSME Units in Indonesia in the period 2016-2018. The results of this study indicate that Liquidity and Solvency have an effect on the development of MSMES both partially and simultaneously.

Keywords: Performance, Micro, Msmes

\section{PENDAHULUAN}

\section{Latar Belakang}

Peran sektor Usaha Mikro, Kecil, dan Menengah di berbagai negara sudah tidak bisa diragukan lagi, apalagi di negara dunia ketiga. Namun pada banyak kasus, sering sekali sektor ini tidak mendapat perhatian yang layak, sehingga keberadaannya sering menjadi keprihatinan banyak pihak, terutama dari para akademisi dan pemerhati yang memiliki keperdulian terhadap daya hidup kelompok UMKM.

Usaha mikro kecil dan menengah (UMKM) merupakan salah satu usaha masyarakat menengah dan bawah yang memiliki peran besar bagi perekonomian Indonesia khususnya dalam kegiatan ekonomi masyarakat baik dari unit usaha dan penyerapan tenaga kerja (Ahifni Anas \& Nurul Huda, 2015)

Hasil pembangunan ekonomi oleh pemerintahan di masa lalu telah menciptakan banyak kemajuan, namun patut diakui bahwa hasil pembangunan juga meninggalkan kesenjangan antar kelompok dalam masyarakat.Pertumbuhan ekonomi dan peningkatan PDB (Gross Domestic Product) ternyata lebih condong memperkuat kelompok ekonomi menengah ke atas, namun kurang berdampak pada gerak sektor riil, khususnya untuk usaha rakyat.

Lambatnya gerak sektor riil dalam negeri menyebabkan impor menjadi satusatunya solusi untuk memenuhi konsumsi masyarakat. Dan meningkatnya impor berdampak pada semakin lambatnya Usaha Mikro, Kecil dan Menengah (UMKM) yang menjadi buffer ekonomi nasional. Sektor yang mewadahi 99,99\% pelaku ekonomi nasional ini, dan menyerap 97\% tenaga kerja nasional ini hampir tidak tersentuh kebijakan yang berarti. Padahal kontribusi kelompok ini, saat ekonomi terkena krisis sangat besar.

Usaha Mikro, Kecil, dan Menengah (UMKM) bertujuan menumbuh kembangkan usaha dalam rangka membangun perekonomian nasional berdasarkan demokrasi ekonomi yang berkeadilan. Ini mengandung makna bahwa UMKM merupakan alat perjuangan nasional untuk menumbuhkan dan membangun perekonomian nasional dengan melibatkan sebanyak mungkin pelaku ekonomi berdasarkan potensi yang dimiliki atas dasar keadilan bagi semua pemangku kepentingan. 
Perkembangan UMKM dengan pertumbuhan ekonomi memiliki gerak yang searah. Perekonomian nasional yang terus tumbuh membuat produk domestik bruto (PDB) menjadi yang terbesar di ASEAN, dan 16 besar dunia di tahun 2015. Rasio utang terhadap PDB Indonesia juga cukup rendah dibanding negara-negara ASEAN lainnya, yaitu 24 persen pada tahun yang sama; ini berpotensi untuk mendorong tumbuhnya UMKM baru.

Daya hidup UMKM sebagai unit usaha, ditentukan oleh banyak faktor. Hasil survei yang dilakukan oleh WEF (2014-2015), melihat hambatan usaha di Indonesia, yang tertinggi adalah korupsi, diikuti oleh akses pembiayaan dan inflasi.

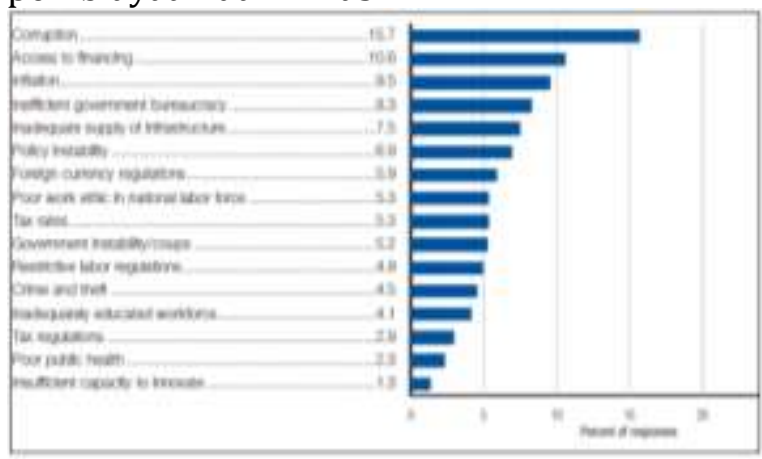

Gambar 1. Hasil Survey

Dalam Penelitian Rusli Simanjuntak (2018) menunjukkan pengaruh yang signifikan dari kinerja pembiayaan mikro bank Islam dengan akad musyarakah dan mudharabah terhadap usaha mikro dan kesejahteraan di Provinsi Jawa Timur. Dalam penelitian Siskawati Solihat dkk (2015) di ketahui bahwa adanya efektifitas kinerja pembiayaan Koperasi Jasa Keuangan Syariah terhadap perkembangan usaha UMKM.

Oleh karena itu dalam penelitian ini akan di lihat lebih jauh pengaruh dari kinerja keuangan lembaga keuangan mikro syariah yakni rasio likuiditas dan solvabilitas terhadap perkembangan UMKM.

\section{Rencana Pemecahan Masalah}

Penelitian ini di lakukan dengan melihat pengaruh kinerja keuangan lembaga keuangan mikro syariah yakni rasio likuiditas dan solvabilitas yang sudah terealisasi terhadap perkembangan unit UMKM periode tahun 2016 sampai dengan 2018.

\section{Rumusan Tujuan Penelitian}

Penelitian ini dilakukan dengan tujuan untuk melihat pengaruh rasio likuiditas dan solvabilitas terhadap perkembangan unit UMKM periode tahun 2016 - 2018

\section{Kajian Teoritik}

Penilaian kinerja keuangan merupakan salah satu metode yang dapat dilaksanakan oleh pihak pengelola agar dapat memenuhi kewajibannya terhadap para penyandang dana atau investor dan juga untuk menggapai tujuan perusahaan yang sudah ditetapkan sebelumnya (Rahmat Nuryanto dkk, 2014). Cara untuk mengetahui baik buruknya kinerja keuangan di suatu lembaga atau perusahaan dapat dilakukan berbagai cara di antaranya dengan menganalisis hubungan dari berbagai pos dalam suatu laporan keuangan perusahaan tersebut (Rahmat Nuryanto dkk, 2014). Beberapa alat analisis prestasi/kinerja keuangan sebuah perusahaan yang digunakan secara umum meliputi rasio likuiditas, rasio solvabilitas serta rasio rentabilitas.

Likuiditas adalah rasio yang menggambarkan kemampuan bank untuk menyelesaikan kewajiban jangka pendeknya (Rahmayeli \& Marlius, 2015). Rasio likuiditas adalah rasio yang menggambarkan kemampuan perusahaan dalam memenuhi kewajiban (utang) jangka pendek (Tanor, Dkk, 2015).

Masalah likuiditas harus diamati agar perusahaan dapat menjaga kredibilitasnya. Tingkat likuiditas yang tinggi dapat menyebabkan perusahaan tidak mampu untuk menjaga kinerja operasionalnya, maka dapat menyebabkan bank dilikuidasi.

Dalam penilaian rasio likuiditas di gunakan untuk menilai sejauh mana kemampuan perusahaan dalam memenuhi semua kewajiban-kewajiban jangka pendek dengan menggunakan jaminan harta lancar yang dimilikinya (Rahmat Nuryanto dkk, 2014).

Rasio solvabilitas digunakan untuk menunjukkan seberapa kemampuan dari perusahaan tersebut bisa memenuhi semua kewajibannya dengan jaminan harta yang dimiliki perusahaan tersebut (Rahmat Nuryanto dkk, 2014).

Dalam penelitian Hartono \& Denny Dwi H (2014) di sebutkan bahwa ada 2 faktor utama yang mempengaruhi perkembangan UMKM yaitu bahan baku dan permodalan dan dalam penelitian yang lain yakni M Kamal Zubair (2016) di sebutkan bahwa ada dua 
variabel yang positif signifikan mempengaruhi sustainabilitas BMT (Lembaga Keuangan Syariah), yaitu sumber daya manusia dan permodalan.

Dalam penelitian Fatimah (2013) di sebutkan bahwa ada hubungan jangka pendek dan jangka panjang antara likuiditas dengan kecukupan modal (CAR) di Bank Umum Syariah, sehingga dalam hal ini jika di "tarik garis lurus" dalam pengamatan sementara bahwa ada hubungan antara likuiditas Lembaga Keuangan Mikro Syariah dengan kecukupan modal lembaga tersebut yang akan di salurkan ke UMKM dalam bentuk pembiayaan (permodalan) yang akan di gunakan untuk kegiatan operasional nya yang nantinya bisa berpengaruh terhadap perkembangan UMKM.

Dalam penelitian Ady Inrawan dkk ( 2020) di sebutkan bahwa solvabilitas berpengaruh terhadap rentabilitas modal sendiri, yang dalam hal jika rentabilitas modal sendiri semakin besar karena pengaruh solvabilitas bisa berpengaruh terhadap jumlah penyaluran pembiayaan (permodalan) kepada UMKM yang dengan sendirinya akan meningkatkan perkembangan UMKM

\section{METODE}

\section{Rancangan Penelitian}

Pendekatan yang digunakan dalam penelitian ini adalah pendekatan kuantitatif, pendekatan kuantitatif adalah suatu penelitian yang dimaksud untuk menilai seberapa besar pengaruh rasio likuiditas dan rasio solvabilitas terhadap perkembangan UMKM periode tahun 2016 - 2018

\section{Populasi dan Sampel}

Data yang di pergunakan adalah rasio likuiditas dan rasio solvabilitas dari Lembaga Keuangan Mikro Syariah yang ada di Indonesia serta Data Perkembangan UMKM (unit) tahun 2016 - 2018

\section{Teknik Pengumpulan Data dan Pengembangan Instrumen}

Jenis data yang digunakan dalam penelitian ini adalah data time series sekunder berupa laporan rasio keuangan yang bersumber dari data sekunder yang diolah dan di dapat dari Data Statistik Industri Keuangan NonBank Syariah (IKNB Syariah) Otoritas Jasa Keuangan dan data perkembangan UMKM dari Kementerian
Koperasi dan Usaha Kecil dan Menengah yang di olah dari data Biro Pusat Statistik (BPS)

\section{Teknik Analisis Data}

Metode analisis data dalam penelitian ini menggunakan analisis regresi linear menggunakan SPSS 25, regresi merupakan teknik statistik (alat analisis) hubungan yang digunakan untuk meramalkan atau memperkirakan dari satu variabel dalam hubunganya dengan variabel yang lain melalui persamaan garis regresi. Analisis regresi bisa berupa garis lurus (linear) dan nonlinear. Sementara analisis regresi pada penelitian ini adalah analisis regresi linear berganda, yaitu regresi yang melibatkan dua variabel yaitu variabel bebas (X1), variabel bebas (X2) dan satu variabel terikat (Y), dimana variabel (X1) dalam penelitian ini adalah rasio likuiditas, variabel (X2) adalah rasio solvabilitas dan variabel (Y) yaitu perkembangan unit UMKM

\section{HASIL DAN PEMBAHASAN}

Sebelum di lakukan analisis regresi linear berganda terlebih dahulu di lakukan uji asumsi klasik yakni :

\section{Uji Normalitas}

Yaitu uji yang bertujuan untuk melihat apakah data yang di pakai terdistribusi normal atau tidak yaitu dengan menggunakan uji Kolmogorov - Smirnov yaitu dengan melihat nilai Signifikansinya (Sig). Dari hasil test memperlihatkan bahwa data terdistribusi normal

Tabel 1. Uji Normalitas

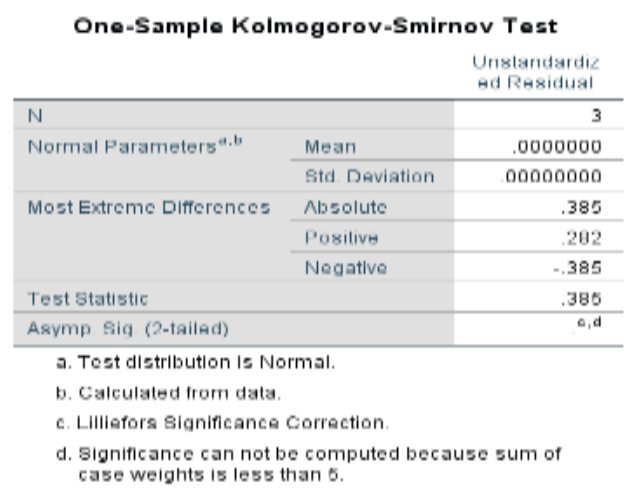

\section{Uji Linearitas}

Uji yang bertujuan untuk mengetahui apakah dua variabel $\mathrm{X}$ mempunyai hubungan yang linear secara signifikan atau tidak terhadap variabel $Y$, uji linearitas ini menggunakan metode scatter plot yaitu masing-masing antara likuiditas keuangan terhadap Perkembangan UMKM dan 
solvabilitas terhadap Perkembangan UMKM. Dari uji yang telah di lakukan terlihat bahwa kedua variabel $\mathrm{X} 1$ dan $\mathrm{X} 2$ mempunyai hubungan Linaer dengan variabel $Y$

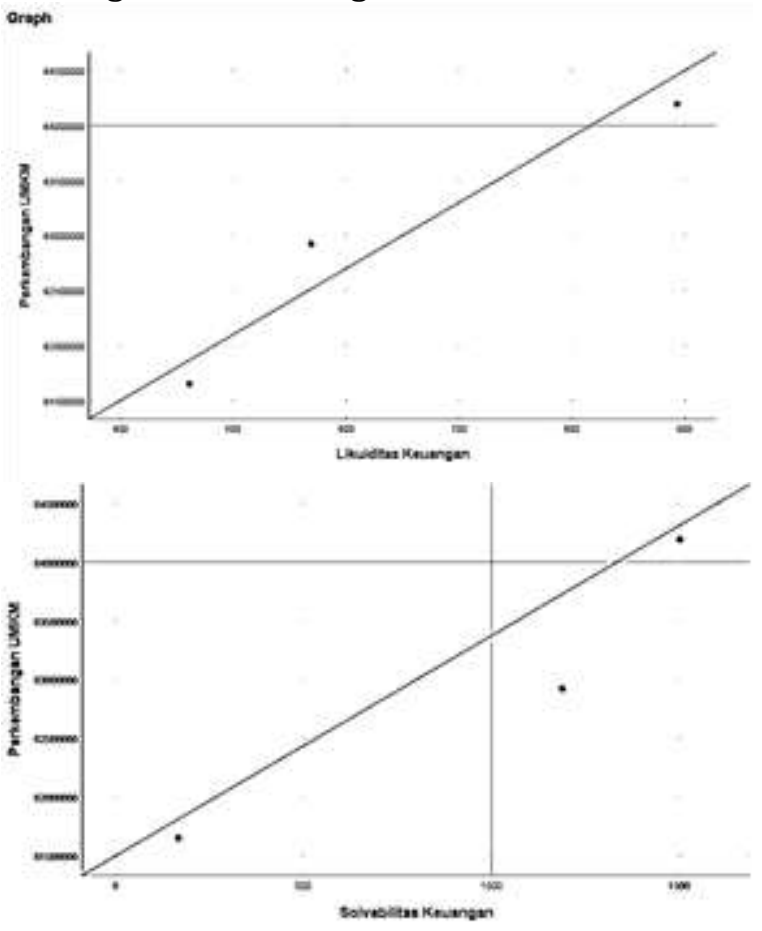

Gambar 2. Uji Linearitas

Uji Heterokedastisitas (Rank Spearman)

Uji yang bertujuan untuk menguji apakah dalam model regresi terjadi ketidaksamaan variance (variasi) atau tidak. Jika variance dari satu pengamatan yang satu ke pengamatan yang lain berbeda maka terjadi heterokedastisitas. Dalam hal ini model regresi yang baik seharusnya tidak terjadi gejala heterokedastisitas. Uji heterokedastisitas ini dengan meatode Rank Spearman dimana tidak terjadi gejala Heterokedastisitas $\operatorname{Sig}(2$ tailed) variabel X1 \& $\mathrm{X} 2>0,05$.

Tabel 2. Uji Heterokedastisitase

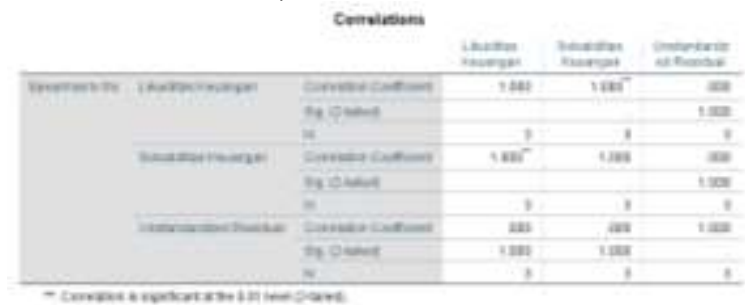

Uji Autokorelasi,

Karena data yang di pakai adalah data time series (runtut waktu) maka dilakukan uji autokorelasi yang bertujuan apakah data yang di pakai terdapat hubungan antara periode $-t$ dengan periode - $t$ sebelumnya. Metode yang di pakai dalam uji ini adalah dengan memakai Uji Durbin Watson dengan kriteria sebagai berikut :

1. Nilai d (durbin Watson) $<\mathrm{dL}$ atau $>4-\mathrm{dL}$ ,maka terdapat autokorelasi

2. Nilai d (durbin Watson) antara dU dan 4$\mathrm{dU}$, maka tidak ada autokorelasi

3. Nilai d (durbin Watson) antara dL dan dU atau antara (4-dU) dan (4-dL), maka tidak menghasilkan kesimpulan pasti

Tabel 3. Uji Autokorelasi

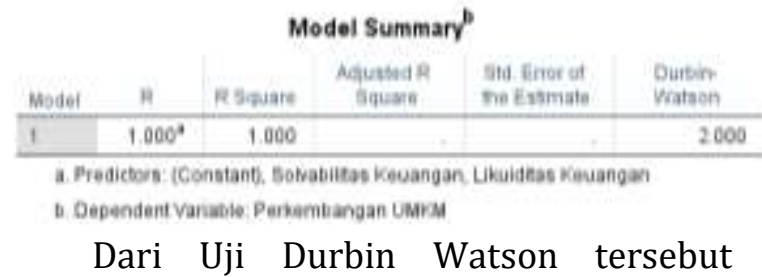
terlihat Nilai DW (d) sebesar 2.000 dimana nilai ini berada di antara nilai dU sebesar 1,546 dan nilai 4-dU sebesar 2,454 (dU < d < 4-dU) maka tidak ada autokorelasi

\section{Uji Multikolinearitas}

Uji Multikolinearitas merupakan bagian dari uji asumsi klasik dalam analisis regresi linear berganda. Tujuan di gunakannya uji multikolinearitas dalam penelitian adalah untuk menguji apakah model regresi di temukan adanya korelasi (hubungan kuat) antar variabel bebas atau variabel independent. Metode Uji ini adalah dengan melihat Nilai Tolerance dan VIF SPSS dengan kriteria sebagai berikut :

1. Jika nilai tolerance $>0,10$ dan nilai VIF $<$ 10,00 maka tidak terjadi multikolinearitas dalam model regresi

2. Jika nilai tolerance $<0,10$ dan nilai VIF $>$ 10,00 maka terjadi multikolinearitas dalam model regresi

Tabel 4. Uji Multikolinearitas

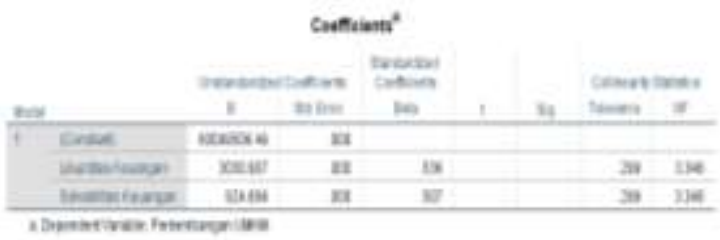

Dalam uji tersebut terlihat bahwa nilai tolerance dari kedua variabel independent (X1 \& X2) masing masing 0,299 $(>0,10)$ dan nilai VIF sebesar 3,346 $(<10,00)$ maka dalam hal ini tidak terjadi multikolinearitas dalam model regresi

\section{Analisis Regresi}

Data yang dipakai dalam analisis regresi linear berganda adalah sebagai berikut : 
Tabel 5. Data Likuiditas dan Solvabilitas Keuangan Lembaga Keuangan Mikro Syariah serta data Perkembangan Unit UMKM tahun

$2016-2018$

\begin{tabular}{|c|c|c|c|}
\hline INDIKATOR & Likuiditas (\%) & Solvabilitas (\%) & $\begin{array}{c}\text { Usaha Mikro, Kecil dan } \\
\text { Menengah (UMKM)/Unit }\end{array}$ \\
\hline Variabel & $\mathrm{X} 1$ & $\mathrm{X} 2$ & $\mathrm{Y}$ \\
\hline 2016 & 46,1 & 167 & 61651177 \\
\hline 2017 & 56,9 & 118,8 & 62922617 \\
\hline 2018 & 89,3 & 150,1 & 64194057 \\
\hline
\end{tabular}

Dari analisis regresi linear berganda di dapat hasil sebagai berikut :

Tabel 6. Analisis Regresi Linear Berganda

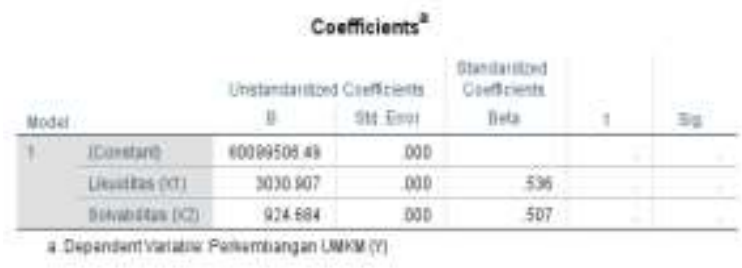

Persamaan regresi yang terbentuk adalah sebagai berikut :

$\mathrm{Y}=\mathrm{a}+\mathrm{x} 1 \mathrm{~b} 1+\mathrm{x} 2 \mathrm{~b} 2$

$Y=60099606,49+3030,907 x 1+924,684 \times 2$ Uji t

Uji t dilakukan dengan tujuan untuk melihat apakah ada pengaruh secara parsial (sendiri - sendiri) antara variabel $X$ terhadap variabel $\mathrm{Y}$, kriteria uji t berdasarkan nilai signifikansinya adalah sebagai berikut :

1. Jika Sig < 0,05 maka ada pengaruh variabel $\mathrm{X}$ secara parsial terhadap variabel $\mathrm{Y}$

2. Jika Sig $>0,05$ maka tidak ada pengaruh variabel X secara parsial terhadap variabel Y.

Dari data yang sudah di olah terlihat bahwa nilai signifikansinya (Sig) sebesar $0,000(<0,05)$ maka dalam hal ini ada pengaruh variabel $X$ secara parsial terhadap variabel $Y$ atau dengan kata lain ada pengaruh variabel Likuiditas dan Solvabilitas secara parsial terhadap variabel perkembangan UMKM

Uji F

Uji $\mathrm{F}$ dilakukan dengan tujuan untuk melihat apakah ada pengaruh secara gabungan (simultan) antara variabel X (X1 dan X2 )

terhadap variabel $\mathrm{Y}$, kriteria uji $\mathrm{F}$ berdasarkan nilai signifikansinya adalah sebagai berikut :

1. Jika Sig $<0,05$ maka ada pengaruh variabel $X(X 1 \& X 2)$ secara simultan terhadap variabel $Y$
2. Jika Sig $>0,05$ maka tidak ada pengaruh variabel X (X1 \& X2) secara simultan terhadap variabel $Y$

Dari data yang telah di olah di ketahui nilai signifikansi (Sig) sebesar $0,000^{\mathrm{b}}$ yang dalam hal ini berarti nilai Sig $<0,05$ yang berarti X1 dan X2 yakni likuiditas dan solvabilitas secara bersama-sama (simultan) berpengaruh terhadap variabel Y (Perkembangan UMKM).

\section{Koefisien Determinasi (R Square)}

Nilai koefisien determinasi di gunakan untuk melihat seberapa besar kontribusi pengaruh yang diberikan variabel $\mathrm{X}$ secara simultan (bersama-sama) terhadap variabel Y . Dari data yang sudah di olah di ketahui nilai R Square sebesar 1.000 yang dalam hal ini variabel X1 dan X2 (Likuiditas dan Solvabilitas) memberikan kontribusi pengaruh sebesar $100 \%$ secara bersama sama (simultan) terhadap variabel $\mathrm{Y}$ (Perkembangan UMKM)

\section{PENUTUP}

\section{Simpulan}

Variabel Likuiditas dan Solvabilitas berpengaruh secara parsial maupun simultan (bersama-sama) terhadap perkembangan UMKM di Indonesia periode tahun 2016 2018 dengan besar pengaruh sebesar 100\%

\section{Saran}

Di perlukan penelitian lebih lanjut terkait pengaruh kinerja keuangan Lembaga Keuangan Mikro Syariah terhadap pertumbuhan bisnis di beberapa sektor usaha UMKM

\section{DAFTAR PUSTAKA}

Alhifni Anas \& Nurul Huda (2015). Kinerja LKMS Dalam Mendukung Kegiatan Ekonomi Rakyat Berbasis Pesantren (Studi Pondok Pesantren Darut Tauhid dan BMT Darut Tauhid). Jurnal Aplikasi Manajemen (JAM) Vol 13 No 4, 2015

Fatimah,Siti (2014). Pengaruh Rentabilitas, Efisiensi dan Likuiditas Terhadap Kecukupan Modal Bank Umum Syariah. Al-Iqtishad: Vol. VI No. 1, Januari 2014

Haque, M. G. (2021). Micro Financial Sharia Non-bank Strategic Analysis: a Study at BMT Beringharjo, Yogyakarta. Budapest International Research and Critics Institute (BIRCI- 
Journal): Humanities and Social Sciences, 4(2), 1677-1686.

Hartono \& Deny Dwi Hartono (2014). Faktor - Faktor yang Mempengaruhi Perkembangan UMKM di Surakarta. Jurnal Bisnis \& Manajemen Vol. 14, No. $1,2014: 15-30$

Inrawan Ady, dkk (2020). Pengaruh Likuiditas dan Solvabilitas terhadap Rentabilitas Modal Sendiri Pada PKPRI di Kabupaten Simalungun. ACCOUNTHINK : Journal of Accounting and Finance. Sekolah Tinggi Ilmu Ekonomi Sultan Agung

Lutfi, A. M., et al. (2021). Pengaruh Capital Adequacy Ratio Dan Bopo Ratio Terhadap Return On Asset Pada Pt. Bank Muamalat Indonesia, Tbk Periode 2010-2019. Jurnal

Ekonomi Efektif, 3(3), 420-428.

Nuryanto, Rahmat dkk (2014). Rasio Likuiditas, Rasio Solvabilitas, Rasio Rentabilitas Koperasi Jasa Keuangan Syariah Di Jawa Tengah. Jurnal Akuntansi Dan Pajak, Vol 15, No. 01, Juli 2014. Sekolah Tinggi Ilmu Ekonomi AAS Surakarta

Putra, IGS., Sunarsi, D., (2020). Comparison of Financial Performance in Banking with High Car and Low Car (Study of Banks Approved in The Kompas 100 Index for The Period 2013-2017). International Journal of Psychosocial Rehabilitation, Vol. 24, Issue 02

Rahmayeli, D. S., \& Marlius, D. (2017). Analisis Kinerja Keuangan Pada PT.
Bank Perkreditan Rakyat (BPR) Batang Kapas Pesisir Selatan.https://doi.org/10.31227/osf. io/sz5db

Sholihat, dkk (2015). Analisis Efektifitas Pembiayaan Lembaga Keuangan Mikro Syariah Terhadap Perkembangan Usaha Nasabah di Sektor Riil (Usaha, Mikro, Kecil dan Menengah). Al-Infaq: Jurnal Ekonomi Islam, Vol. 6 No. 1, Maret 2015 pp. 1-58 Program Studi Ekonomi Syari'ah FAIUIKA Bogor

Simanjuntak, Rusli (2018). Pengaruh Kinerja Pembiayaan Mikro Musyarakah dan Mudharabah di Bank Syariah terhadap Sektor Usaha Mikro di Provinsi Jawa Timur. Indonesian Journal of Islamic Economics \& Finance Vol. 1, No. 1, Juni 2018: 32-53.

Sugiarto, S., Putra, IGS., (2020). The role of communication climate on the performance of PT. Lazada Express Bandung employees with work motivation as an intervening variable. International Journal of Research in Business and Social Science (2147-4478) 9(5).

Zubair, Muhammad Kamal (2016). Analisis Faktor-Faktor Sustainabilitas Lembaga Keuangan Mikro Syariah. IQTISHADIA Vol. 9, No. 2, 2016, 201226 P-ISSN: 1979-0724, E-ISSN: 25023993DOI:

http://dx.doi.org/10.21043/iqtishadi a.v9i2. 